\title{
A METHOD OF MULTI-ATTRIBUTE ASSESSMENT USING IDEAL ALTERNATIVE: CHOOSING AN APARTMENT WITH OPTIMAL INDOOR ENVIRONMENT
}

\author{
Darius KALIBATAS ${ }^{1}{ }^{凶}$, Edmundas Kazimieras ZAVADSKAS ${ }^{2}$ \\ and Diana KALIBATIENE ${ }^{3}$ \\ ${ }^{1}$ Department of Construction Technology and Management, Faculty of Civil Engineering, \\ Vilnius Gediminas Technical University, Sauletekio al. 11, LT-10223 Vilnius, Lithuania \\ E-mail:darius.kalibatas@vgtu.lt \\ ${ }^{2}$ Department of Construction Technology and Management, Faculty of Civil Engineering, \\ Vilnius Gediminas Technical University, Sauletekio al. 11, LT-10223 Vilnius, Lithuania \\ ${ }^{3}$ Department of Information Systems, Faculty of Fundamental Sciences, Vilnius Gediminas \\ Technical University, Sauletekio al. 11, LT-10223 Vilnius, Lithuania
}

Received 30 December 2011; accepted 3 May 2012

\begin{abstract}
An indoor environment of each building depends on a number of criteria, like temperature, humidity, noise, etc. Therefore, multi-attribute decision making (MADM) methods are used to assess alternatives and to choice the rational one. In this paper we suggest to add a concept of ideal alternative into assessment using MADM, since it allows both to determine the optimal solution and the deviation of each alternative (an indoor environment of a building) from the optimal values, e.g. ideal alternative. Therefore, a method of multi-attribute assessment using ideal alternative (MAAIA) is formulated in this paper. It is applied for the MOORA method to assess an indoor environment of apartments in block houses situated in Naujoji Vilnia, Vilnius, Lithuania. Obtained results of the assessment show that the proposed method is useful for decision support and assessment of alternatives.
\end{abstract}

KEYWORDS: Indoor environment; Multi-attribute decision making; Ideal alternative; MOORA method; Passive house

\section{INTRODUCTION}

As presented in (Triantaphyllou, 2000; Zavadskas and Turskis, 2011), multi-criteria decision making (MCDM) has been on of the fastest growing area in conflict management and decision making, since nowadays business problems become multi-person and multi-criteria situations. In theory many methods have been proposed and developed to solve this problem in numerous ways. However, there is no the best method or a standard.
In this paper, a method of Multi-Attribute Assessment based on the Ideal Alternative (MAAIA), which is developed from the idea described in (Kalibatas et al., 2011), is proposed. This method advocate using of the ideal alternative in the multi-attribute decision making (MADM), since it allows both to determine the optimal solution among compared and the deviation of each alternative (an indoor environment of a building) from the optimal values, e.g. ideal alternative. Another advantage of the proposed method is that it can be applied 
with different MADM methods, like WSM (the weighted sum model), TOPSIS (the Technique for Order Preference by Similarity to Ideal Solution), etc.

In the case study, the proposed method is applied with the MOORA method to assess an indoor environment of six apartments in block flat houses in Naujoji Vilnia, Vilnius, Lithuania. Obtained results show that the proposed method helps to assess and choose a rational living and/or working place reasonably.

The rest of paper is structured as follows. Section 2 presents the related work on MADM methods and assessment of indoor environment. Section 3 presents a description of the proposed method of multi-attribute assessment using ideal alternative (MAAIA). Section 4 describes the application of MAAIA to the assessment of an indoor environment of apartments (living places) using the MOORA method. Section 5 presents a case study of the assessment of six apartment houses in Naujoji Vilnia, Vilnius, Lithuania. Finally, Section 6 concludes the paper.

\section{THE RELATED WORK}

\subsection{MADM methods}

Quite a number of methods have been proposed for solving multi-attribute decision making (MADM) problems. MADM methods are successfully applied in a great number of areas, like: risk analysis (Zavadskas et al., 2010a; Banaitienè et al., 2011), optimization of well being (Balezentis et al., 2011), doppler selection (Baležentis and Baležentis, 2011), assessment of building redevelopment in Lithuanian rural areas (Antucheviciene et al., 2010), the assessment of sustainability of a residential building (Medineckiene et al., 2011), the facilities sector (Brauers and Zavadskas, 2009), selection management strategy (Zavadskas et al., 2011), assessment of partnering relations in construction enterprises (RadziszewskaZielina, 2010), evaluation of contracts for con- struction (Podvezko et al., 2010), design of coordinated energy and environmental policies (Greening and Bernow, 2004), building refurbishment (Kaklauskas et al., 2005), passive houses multiple criteria analysis (Kaklauskas et al., 2011), renovation (Martinaitis et al., 2007; Martinaitis et al., 2004; Zavadskas et al., 2008) and revitalization (Antucheviciene et al., 2011), selection the most appropriate and safe foundation instalment alternative for building (Zavadskas et al., 2010b), indoor environment analysis ( Zavadskas et al., 2011; Mui and Chan, 2006; Rutman et al., 2005; Wong et al., 2006), regional development in Lithuania considering multiple objectives by the MOORA method (Brauers et al., 2010), MultiMOORA for the EU member states updated with fuzzy number theory (Brauers et al., 2011), risk analysis (Yazdani et al., 2011), etc.

The similarity of all MADM techniques, as presented by Triantaphyllou (2000) are: alternatives and attributes.

Alternatives represent different choices available to the decision maker. Attributes (referred to as "goals" or "decision criteria") represent the different dimensions from which the alternatives can be viewed. Since different criteria represent different dimensions of the alternatives, they may conflict with each other. For instance, cost may conflict with profit. Different criteria may be associated with different units of measure. For instance, cost and distance may be measured in terms of metre and kilometre. Therefore, some authors, like Zavadskas (1987), propose to normalise criteria. In this sense, normalisation - is the process, during which criteria with different dimensions translated into criteria without dimensions.

It is accepted that a MADM problem is expressed in a matrix format. A decision making matrix $A$ is an ( $m \times n)$ matrix in which element $a_{i j}$ is the performance of alternative $A_{i}$ when it is evaluated in terms of decision criterion $C_{j}$ (for $i=1,2, \ldots, m$ and $j=1,2, \ldots, n$ ) (Trian- 
taphyllou, 2000). It is also assumed that the decision maker has determined the weights of relative performance of the decision criteria. Weights are denoted as $w_{j}$ for $j=1,2, \ldots, n$. Formulas used for normalization of decision matrices depend on MADM method.

The main steps in utilizing any decisionmaking technique are as follows: 1) Determine the relevant criteria and alternatives; 2) Attach numerical measures to the relative importance of the criteria and to the impacts of the alternatives on these criteria; 3) Process the numerical values to determine a ranking of each alternative.

Because of a number of MADM methods and techniques a problem of choosing a MADM method or a technique arises. Moreover, different techniques may yield different results when applied to the same problem (Zanakis et al. 1998). The problem considered in this study consists of a decision matrix input of $N$ criteria weights and ratings of $L$ alternatives on each criterion.

Zanakis et al. (1998) compared ELECTRE, TOPSIS, Multiplicative Exponential Weighting (MEW), Simple Additive Weighting (SAW), and four versions of AHP (original vs. geometric scale and right eigenvector vs. mean transformation solution) methods performance. Simulation parameters are the number of alternatives, criteria and their distribution. The solutions are analyzed using twelve measures of similarity of performance. Dissimilarities in weights produced by these methods become stronger in problems with few alternatives. However, the corresponding final rankings of the alternatives vary across methods more in problems with many alternatives. The distribution of criterion weights affects the methods differently. In general, all AHP versions behave similarly and closer to SAW than the other methods. ELECTRE is the least similar to SAW (except for closer matching the topranked alternative), followed by MEW. TOP-
SIS behaves closer to AHP and differently from ELECTRE and MEW, except for problems with few criteria. A similar rank-reversal experiment produced the following performance order of methods: SAW and MEW (best), followed by TOPSIS, AHPs and ELECTRE.

The Weighted Sum Model (WSM) is probably the most commonly used approach especially in single dimensional problems. Difficulty with this method emerges when it is applied to multi-dimensional decision-making problems (Triantaphyllou, 2000). In combining different dimensions, and consequently different units, the additive utility assumption is violated.

The Weighted Product Model (WPM), which some of the first references can be find in Bridgman (1922), Miller and Starr (1969), is very similar to the WSM (Triantaphyllou, 2000). The main difference is that instead of addition in the method there is multiplication. The advantage of the method is that instead of actual values it can use relative ones, e.g. it can be used successfully in single- and multidimensional decision-making problems.

In the Analytic Hierarchy Process (AHP), the decision maker carries out simple pairwise comparison judgements, which are then used to develop overall priorities for ranking the alternatives (Saaty and Vargas, 2001). It is similar to the WSM, but it uses relative values instead of actual ones. Thus, it can be used in single- and multi-dimensional decision-making problems. However, Belton and Gear (1983) show that an inconsistency can occur in the AHP method. Therefore, they proposed a revised version of the AHP method. According to the authors this inconsistency comes from the fact that the relative values for each criterion sum up to one. They propose to divide each relative value by the maximum value of the relative value.

ELECTRE methods comprise two main procedures: construction of one or several outranking relation(s) followed by an exploitation 
procedure. The construction of one or several outranking relation(s) aims at comparing in a comprehensive way each pair of actions. The exploitation procedure is used to elaborate recommendations from the results obtained in the first phase. The nature of the recommendations depends on the problematic (choosing, ranking or sorting).

The method of multi-attribute complex proportional evaluation (COPRAS) is based on the initial data normalization method. It assumes that the significance and priority of the investigated alternatives depend directly on and are proportional to a system of criteria adequately describing the alternatives and to the values and weights of the attributes (Kaklauskas et al., 2010). The system of attributes is determined and their values and initial weights are calculated. All this information can be corrected by stakeholders (customer, users, etc.), taking into consideration their goals and existing capabilities.

The TOPSIS (technique for order preference by similarity to an ideal solution) method was developed by Hwang and Yoon (1981). The basic principle is that the chosen alternative should have the shortest distance from the ideal solution and the farthest distance from the negative-ideal solution. In TOPSIS, the ideal solution is the best alternative among chosen alternatives for the assessment, and the negative-ideal solution is the worst alternative among chosen alternatives for the assessment. E.g. the concepts of local ideal and negative-ideal solutions are used.

The MCDM method VIKOR (Opricovic and Tzeng, 2004) is based on an aggregating function, which represents closeness to the ideal solution. In VIKOR linear normalization is used to eliminate the units of criterion functions. The VIKOR method determines a compromise solution, providing a maximum "group utility" for the "majority" and a minimum of an individual regret for the "opponent". The
TOPSIS method determines a solution with the shortest distance to the ideal solution and the greatest distance from the negative-ideal solution, but it does not consider the relative importance of these distances. A comparative analysis of VIKOR and TOPSIS is presented in Opricovic and Tzeng (2004).

However, none of the methods reviewed below uses the concept of the global ideal solution or global ideal alternative, which means the best possible alternative in a space. However, the main disadvantage of using the concept of the global ideal solution is that not in all cases it exists. For MADM methods such global ideal solution can be defined, since MADM studies problems with discrete decision space. For such attributes, like cost, may be difficult to determine optimal value, since the least price is preferred. Therefore, we suggest using of the best alternative among chosen alternatives for the assessment, like in TOPSIS.

Chakraborty (2011) in his article explores the application of an almost new MODM method, i.e., the multi-objective optimization on the basis of ratio analysis (MOORA) method to solve different decision-making problems as frequently encountered in the real-time manufacturing environment. Six decision-making problems which include selection of (a) an industrial robot, (b) a flexible manufacturing system, (c) a computerized numerical control machine, (d) the most suitable non-traditional machining process for a given work material and shape feature combination, (e) a rapid prototyping process, and (f) an automated inspection system are considered in his paper. In all these cases, the results obtained using the MOORA method almost corroborate with those derived by the past researchers which prove the applicability, potentiality, and flexibility of this method, in comparison with AHP, TOPSIS, VIKOR, ELECTRE and PROMETHEE, while solving various complex decision-making problems in present day manufacturing environment. 


\subsection{Indoor environment of dwelling houses}

There are a number of works, where a comparison of indoor environment of different dwelling-houses are analysed and the best alternative among chosen is determined. However, first of all it is necessary to choose attributes of the assessment.

Hui et al. (2007, 2008) analyse indoor air quality and ventilation efficiency according to Carbon dioxide $\left(\mathrm{CO}_{2}\right)$. However, other indicators are not taken into account.

Bluyssen (2008) states that over the last century, management of the indoor environment was focused only on its single components (thermal comfort, noise, light, air quality) and not attention was paid on interrelations between these components. Although standards and guidelines are met, the quality of the indoor environment, as experienced by the occupants, could be not acceptable and unhealthy, causing health and comfort problems. Nowadays, it is important to pay attention and evaluate such indoor air pollutants, like volatile organic compounds (VOC), VOC groups, ammonia, and formaldehyde in newly established residential buildings with low-emitting materials. The paper (Bluyssen, 2008) presents contribution of pollutants from different structures (floor, walls, and ceiling) to indoor air concentration levels during the first year after the building was taken into use.

Kavraz and Abdulrahimov (2009) analyse an importance of noise reduction for goodness of indoor being. Other pollutants and attributes of indoor environment, like dust (Latif et al., 2009), nitrogen oxides (Vilcekova and Senitkova, 2009), energy saving (Yik and Lun, 2010), toxic moulds (Singh et al., 2010), lighting installations (Boyce, 2010), housing environment (Braubach, 2007), thermal environment (Cheong et al., 2006; Gulyas et al., 2006), etc. are analysed, also. However, not all authors present a continuous method for evaluating an indoor environment. The devia- tion from hygienic norms is not mentioned in many researches, also.

Since in Lithuania there are two seasons heating season and not-heating season - it is necessary to take into account heating costs, which indirectly influence an indoor environment of dwelling-houses. The passive house concept is used to define a house with minimal energy losses, what allow minimizing heating cost and environmental (outdoor and indoor) damage, and maximizing habitants' satisfaction of indoor environment. Unfortunately, not all dwelling-houses in Lithuania can be referred as passive houses. According to PHI (2010) and Ludeman (2008), annual heat requirement in a passive house is $\leq 15 \mathrm{kWh} / \mathrm{m}^{2}$ / year $(4.75 \mathrm{kBtu} / \mathrm{sf} /$ year).

According to NuTech Renewables (2011), a Passive House Standard defines the five methods in which the performance criteria can be delivered. They are as follows:

1. Optimisation of the building's form and orientation - this allows to reduce heat loss and maximise solar gain. The following requirements should be kept to achieve this criterion: a) minimize surface area to volume ratios $(\mathrm{S} / \mathrm{V})$ of the building, b) capture solar heat gains by sizing south facing glazing; c) minimize over shading through other buildings or objects, d) avoid summer overheating by considering forms of shading, e) reduce exposed areas by huddling buildings together.

2. Elimination of thermal bridges in insulation $\left(0.15 \mathrm{~W} / \mathrm{m}^{2} \mathrm{~K}\right.$ and triple glazing $\left(<0.8 \mathrm{~W} / \mathrm{m}^{2} \mathrm{~K}\right)$. The following requirements should be kept to achieve this criterion: a) low wall, roof and floor U-values $\left(\leq 0.15 \mathrm{~W} / \mathrm{m}^{2} \mathrm{~K}, \sim 300 \mathrm{~mm}\right.$ of insulation); b) using of thermal bridge-free construction; c) the thermal envelope has to be designed and build to highest specifications; d) high performance glazing with whole window U-values $\left(\leq 0.8 \mathrm{~W} / \mathrm{m}^{2} \mathrm{~K}\right)$.

3. Using of air tightening fabric $(<0.6$ air exchanges $\sim 1.6 \mathrm{~m}^{2} / \mathrm{h} / \mathrm{m}^{3}$ at $50 \mathrm{~Pa}$ ) for insulation. The following requirements 
should be kept to achieve this criterion: a) reducing air permeability, b) using air tightness foil for all joints of building components, c) air permeability testing.

4. Increasing efficiency of mechanical ventilation and heat recovery $>75 \%$. The following requirements should be kept to achieve this criterion: a) use an 80-90\% efficient heat exchanger and mechanical ventilation to ensure appropriate home ventilation without heat loss, b) correct design and installation of the low power fans and ducting, c) bypassing the heat exchanger in summer, d) additionally ventilate the house by opening windows.

5. Maximization of primary energy demand: $120 \mathrm{kWh} / \mathrm{m}^{2} /$ year and applying renewable energy systems when appropriate. The following requirements should be kept to achieve this criterion: a) specify low energy light fittings and appliances, b) insulate domestic hot water pipes and cylinders, c) provide hot water with solar thermal panels and storage, d) reduce $\mathrm{CO}_{2}$ emissions with renewable energy systems.

Concluding these methods of reaching an indoor environment of a passive house, an appropriate isolation and ventilation should be achieved mainly.

Venckus et al. (2010) analyse the most popular European mid-region passive house concept and the energetic performance of the house, designed and built according to its requirements. The main differences of this concept to the normative requirements of Lithuanian building regulations and proposals to improve provisions for the construction of low energy buildings in Lithuania are provided. As can be seen from the related work, the assessment of indoor environment of different dwelling-houses and choosing optimal alternative is a relevant problem. However, only a few works compare a present state of an indoor environment of dwelling-houses with standards, like the Lithuanian hygienic norm (HN 42:2009 "Microclimate of dwelling-houses and public facilities"), ISO EN 7730 or the Passive House standard (NuTech Renewables, 2011). The comparison of a present state of an indoor environment of dwelling-houses with standards and norms is important, since it allows determining the deviation from and matching the chosen alternatives with the optimal indoor environment (the ideal indoor environment). This is important, since all alternatives chosen for the assessment can be far from the optimal one and the comparison among them does not present the global view. Therefore, in the next section a method of multi-attribute assessment using ideal alternative (MAAIA) is presented.

According to the related work (Section 2) and geographic location of observed dwelling-houses the authors of this paper are going to study the following attributes in this paper: air exchange $\left(\mathrm{m}^{3} / \mathrm{h}\right)$, relative air humidity (percents), air temperature $\left({ }^{\circ} \mathrm{C}\right)$, air velocity $(\mathrm{m} / \mathrm{s})$, surface area to volume ratio $(1 / \mathrm{m})$, noise isolation $(\mathrm{dB})$, annual heat requirement $\left(\mathrm{kWh} / \mathrm{m}^{2} /\right.$ year $)$. As can be seen, in this paper the ideal indoor environment is close to the passive house, since in Lithuania and in other countries with two seasons the energy saving is a relevant problem.

\section{A METHOD OF MULTI-ATTRIBUTE ASSESSMENT USING IDEAL ALTERNATIVE (MAAIA)}

Based on the related work (Section 2), the following steps of the method of multi-attribute assessment using ideal alternative (MAAIA) are defined:

1. Determine the relevant attributes and alternatives. In this step compared alternatives and attributes, according to which the selected alternatives will be assessed, are determined. E.g. a se of alternatives $A$ and a set of decision criteria (attributes) $C$ are selected (see section 2.1. and Triantaphyllou, 2000).

2. Attach numerical measures to the relative importance of the attributes and to the impacts of the alternatives on these attributes. In this step measurements of 
alternatives according to the selected attributes are performed and importance of the attributes is determined. E.g. a decision making matrix is defined. Measurements of alternatives are performed using specific devices. Importance of the attributes is determined empirically, like using experts, or theoretically, making a review of the related area.

3. Determine the ideal alternative. The ideal alternative is determined according to the standards and norms. E.g. the optimal values of attributes are determined. If there is no a standard or a norm for this attribute, like for example for price or a cost.

4. And the ideal alternative is included into the assessment as an additional alterna- tive. E.g. it is added to the decision making matrix.

5. Process the numerical values to determine a ranking of each alternative. The particular MADM method is chosen and the numerical values presented by a decision making matrix are processed according to the selected method.

6. Determine the deviation and matching of the chosen alternatives from the ideal alternative. In this step the deviation of all assessed alternatives from the ideal one is analysed. Different comparative methods can be used for the analysis of the deviation.

The schema of applying the proposed method is presented in Figure 1.

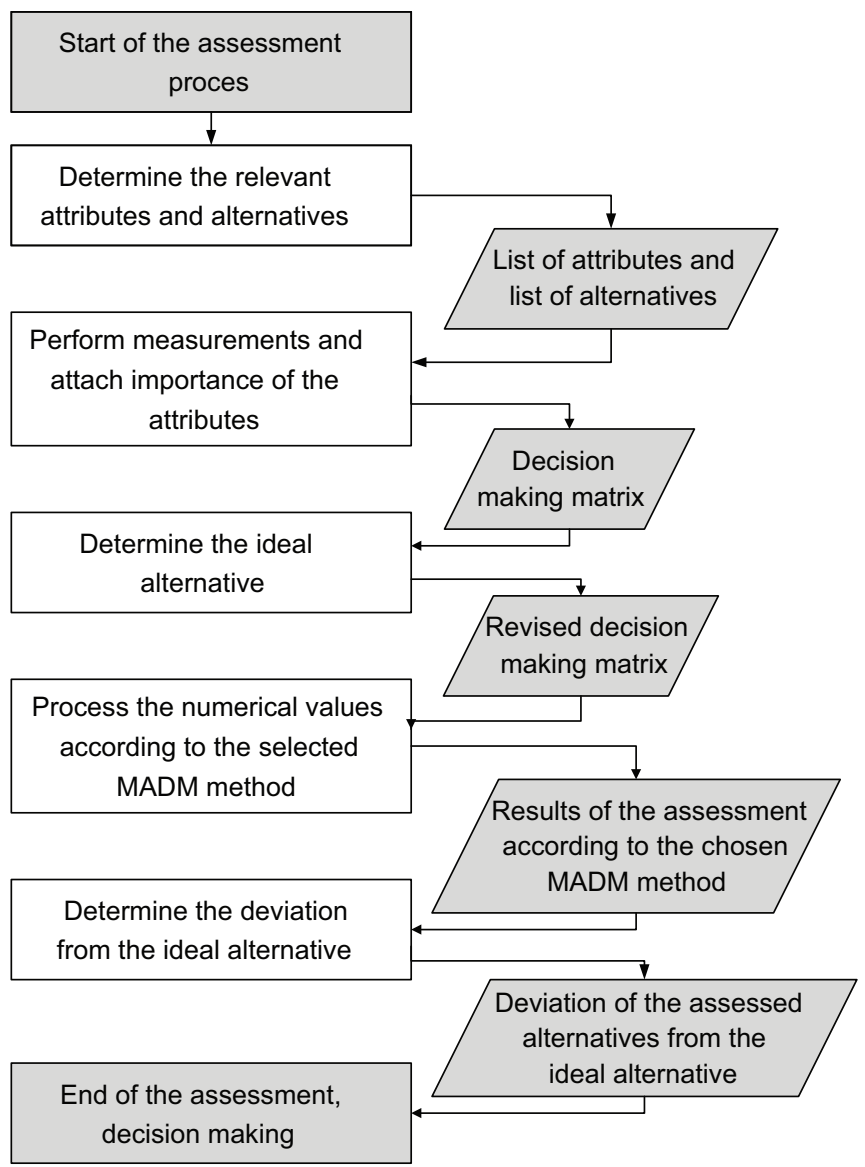

Figure 1. The schema of the multi-attribute assessment using ideal alternative (a white rectangular presents a step of the assessment (process), a grey rectangular - start and/or end of the assessment, a parallelogram - input and/or output of a step) 
The proposed method is wide applicable, since it is not dependent on any MCDM method.

\section{APPLICATION OF MAAIA TO THE ASSESSMENT OF AN INDOOR ENVIRONMENT OF DWELLING- HOUSES USING MOORA}

\subsection{Attributes of the assessment of an indoor environment}

Based on the related work, the attributes of evaluating an indoor environment of dwellinghouses are selected. They are as follows:

- air exchange, $\mathrm{m}^{3} / \mathrm{h}$,

- relative air humidity, percents,

- air temperature, ${ }^{\circ} \mathrm{C}$,

- air velocity, $\mathrm{m} / \mathrm{s}$,

- surface area to volume ratio, $1 / \mathrm{m}$,

- noise isolation, $\mathrm{dB}$,

- annual heat requirement, $\mathrm{kWh} / \mathrm{m}^{2} /$ year.

37 experts were questioned to determine the significance of the presented attributes. The results of questioning were processed according to Kendall (1970) and Zavadskas et al. (2010c) and summarised in Table 1.

Table 1 presents attributes and their weights $\left(w_{i}\right)$, which equal to the sum of significance of a particular attribute divided to the sum of significance of all attributes. Significance is defined as an integer number from 1 to 7 (we have 7 attributes), where 7 is the most important and 1 is the least important. Moreover, a number can appear only once evaluating significance. The correctness of experts' answers was determined by defining their compatibility as presented in Kendall (1970) and Zavadskas et al. (2010c). The result is acceptable.

As can be seen from Table 1, the third (air temperature) and seventh (annual heat requirement) attributes have the strongest impact on the assessment of dwelling-houses.

New attributes, like chemical and biological agents, dusts, etc., can be included into the assessment. We are concentrated on the listed before seven attributes, since according to the experts they are the main in the assessment of indoor environment of dwelling-houses.

Table 1. Weights $\left(w_{i}\right)$ of attributes

\begin{tabular}{ll}
\hline Attribute & Weight (wj) \\
\hline 1. Air exchange & 0,1071 \\
2. Relative air humidity & 0,1429 \\
3. Air temperature & 0,2143 \\
4. Air velocity & 0,0714 \\
5. Surface area to volume ratio & 0,0357 \\
6. Noise isolation & 0,1786 \\
7. Annual heat requirement & 0,2500 \\
\hline Sum: & 1 \\
\hline
\end{tabular}

\subsection{The ideal indoor environment according to the selected attributes}

The ideal indoor environment, e.g. the ideal alternative, is defined by assigning optimal values to the selected attributes. These optimal values are taken from the Lithuanian hygienic norm (HN 42:2009) and other standards, like (Olesen, 2004), ISO EN 7730 2005, (PHI, 2010; Ludeman, 2008) and the Passive House standard (NuTech Renewables, 2011). Table 2 presents optimal values of the selected attributes.

During the process of assessment of dwelling-houses, an area of a floor and a high of a floor are known often. Therefore, volume of a dwelling-house or an apartment is calculated as $V=A^{*} h$, where $A$ presents area of a dwelling-house or an apartment, $h$ - a high of a floor. A surface area of a dwelling-house or an apartment $S$ is measured and calculated by performing measurements of this dwellinghouse or an apartment.

Due to individual differences it may be very difficult to satisfy everybody in a space (Olesen, 2004). Individual control of the thermal environment or individual adaptation (clothing, activity) will, however, increase the level of acceptance. In this research we take optimal values according to the standards; however, they can be refined according to the individual needs. 
Table 2. Optimal values for the selected attributes

\begin{tabular}{lll}
\hline Attribute & Measuring units & Optimal value \\
\hline Air exchange & $\mathrm{m}^{3} / \mathrm{h}$ & $\sim 90^{*}$ (Seppanen and Vuolle, 2000) \\
Relative air humidity & Percents $(\%)$ & $50^{* *}$ \\
Air temperature & ${ }^{\circ} \mathrm{C}$ & $22^{* *}$ \\
Air velocity & $\mathrm{m} / \mathrm{s}$ & $\geq 0.15^{* *}$ at cold season \\
& & $\geq 0.25^{* *}$ at worm season \\
Surface area to volume ratio & $1 / \mathrm{m}$ & Minimal surface area to volume ratio is \\
& & preferred. A cube building has a minimal \\
& & surface area to volume ratio. This ratio will \\
& & be determined during the experiment using \\
& formula $R_{S / V}=S / V$
\end{tabular}

* According to the Passivhaus Institute, the appropriate air change rate for dwelling houses is between 0.3 and 0.4 times for volume of the building per hour. This maintains high indoor air quality. The PHPP software suggests that $30 \mathrm{~m}^{3}$ per person per hour should be provided in dwelling houses to ensure good air quality (SPHC 2012). Since in this research dwelling houses with 3 occupants are analysed, $90 \mathrm{~m}^{3} / \mathrm{h}$ of fresh air is chosen.

** Average comfort values of air temperature, relative air humidity and air velocity according to the Lithuanian Technical regulations of construction "Heating, ventilation and air exchange" (STR 2.09.02:2005).

*** Surface area to volume ratio is calculated according to the presented formula in Table 2 , where $R_{S / V}$ presents ratio, $S$ is a surface area of a dwelling-house or an apartment, $V$ is a volume of a dwelling-house or an apartment. Note: an outside surface area, not all surface area, of a flat, should be taken to calculate ratio of an apartment in a block apartment house, since heat of an apartment is lost through the outside surface. An ideal value equals to the minimal value of measurements.

**** According to the Lithuanian Technical regulations of construction "Noise protection of inside and outside environment" (STR 2.01.07:2003), an acceptable noise level of a transport vehicles outside the building is $55 \mathrm{~dB}$.

$* * * * *$ The value is taken according to the Passive House requirement. Though, as in any dwelling house, a Passive House requires a system that provides domestic hot water (DHW), the Passivhaus Standard is achievable without solar based water heating (SPHC 2012). In this research we do not include a DHW system into annual heat requirement.

\subsection{The MOORA method}

The Multi-Objective Optimization on the basis of Ratio Analysis (MOORA) method is used for the assessment of an indoor environment of dwelling-houses in this paper. It was chosen for this research according to the related work and results presented in (Chakraborty, 2011). The MOORA (Brauers and Zavadskas, 2006; Brauers and Zavadskas, 2009; Brauers et al., 2008; Chakraborty, 2011) procedure consists of the following steps:

Step 1: Constructing a decision matrix, which shows the performance of different alternatives with respect to various attributes (1):

$$
\begin{aligned}
& X=\left[x_{i j}\right]=\left[\begin{array}{cccc}
x_{11} & x_{12} & \ldots & x_{1 n} \\
x_{21} & x_{22} & \ldots & x_{2 n} \\
\ldots & \ldots & \ldots & \ldots \\
x_{m 1} & x_{m 2} & \ldots & x_{m n}
\end{array}\right], i=1, \ldots, \\
& j=1, \ldots, n
\end{aligned}
$$

where: $x_{i j}$ is the performance measure of $i^{\text {th }}$ alternative on $j^{\text {th }}$ attribute; $m$ is the number of alternatives; and $n$ is the number of attributes.

Step 2: Constructing a ratio system, in which each performance of an alternative on an attribute is compared to a denominator, which is a representative for all the alternatives concerning that attribute. In Brauers and 
Zavadskas (2006) various ratio systems, such as total ratio, Schärlig ratio, Weitendorf ratio, Jüttler ratio, Stopp ratio, Körth ratio etc., are considered and concluded that for this denominator, the best choice is the square root of the sum of squares of each alternative per attribute. This ratio can be expressed as presented in (2):

$$
x_{i j}^{*}=\frac{x_{i j}}{\sqrt{\sum_{j=1}^{m} x_{i j}^{2}}}, i=1, \ldots, m, j=1, \ldots, n,
$$

where: $x_{i j}^{*}$ is a dimensionless number, which belongs to the interval $[0,1]$ and represents the normalized performance of $i^{\text {th }}$ alternative on $j^{\text {th }}$ attribute.

Step 3: For multi-objective optimization, these normalized performances are add$\boldsymbol{e d}$ in case of maximization (for beneficial attributes) and subtracted in case of minimization (for non-beneficial attributes). Then the optimization problem becomes as follows (3):

$$
y_{i}=\sum_{j=1}^{g} x_{i j}^{*}-\sum_{j=g+1}^{n} x_{i j}^{*}, j=1, \ldots, n,
$$

where: $g$ is the number of attributes to be maximized; $(n-g)$ is the number of attributes to be minimized; and $y_{i}$ is the normalized assessment value of $i^{\text {th }}$ alternative with respect to all the attributes.

Step 4: Assigning weights to attributes. In some cases some attributes are more important than the others. In order to give more importance to an attribute, it could be multiplied with its corresponding weight (significance coefficient) (Brauers and Zavadskas, 2009). Then the optimization problem becomes as follows (4):

$$
y_{i}=\sum_{j=1}^{g} w_{j} x_{i j}^{*}-\sum_{j=g+1}^{n} w_{j} x_{i j}^{*}, j=1, \ldots, n,
$$

where: $w_{j}$ is the weight of $j^{\text {th }}$ attribute, which can be determined as presented in Section 4.1.
The $y_{i}$ value can be positive or negative depending of the totals of its maxima (beneficial attributes) and minima (non-beneficial attributes) in the decision matrix.

Step 5: Determining the final preference. An ordinal ranking of $y_{i}$ shows the final preference. Thus, the best alternative has the highest $y_{i}$ value, while the worst alternative has the lowest $y_{i}$ value. The most preferable alternative $K$ is found according to (5):

$$
K=\max _{j} y_{j}, j=1, \ldots, n .
$$

\subsection{Applying MOORA to the MAAIA method}

In this section, the overall description of the proposition by using the MOORA method is present. The main steps in utilizing MOORA are as follows:

1. Determine the relevant attributes and alternatives (dwelling-houses or apartments). Attributes used for the assessment of an indoor environment of dwelling-houses or apartments are: air exchange $\left(\mathrm{m}^{3} / \mathrm{h}\right)$, relative air humidity (percents), air temperature (C), air velocity $(\mathrm{m} / \mathrm{s})$, surface area to volume ratio $(1 / \mathrm{m})$, noise isolation $(\mathrm{dB})$ and annual heat requirement $\left(\mathrm{kWh} / \mathrm{m}^{2} /\right.$ year $)$.

2. Attach weights to the selected attributes.

3. Perform measurements to determine the values of the attributes.

4. Determine the ideal indoor environment by attaching optimal values to the selected attributes.

5. Apply the MOORA method to process the obtained measures.

6. Choose the rational indoor environment and compare it with the defined ideal indoor environment.

The next section presents the case study of evaluating indoor environment of six apartments in block apartment houses in Naujoji Vilnia, Vilnius, Lithuania. 


\section{ASSESSMENT OF APARTMENTS IN NAUJOJI VILNIA BY MAAIA}

The proposed MAAIA method using MOORA was applied to assess the 6 apartments in block apartment houses situated in Naujoji Vilnia, Vilnius, Lithuania. The values of attributes were measured by Metrel device MI 6201 EU, having the calibration certificate. The data of measurements is presented in Table 3 .
The data of measurements are given in a decision making matrix (Table 2), where columns contain attributes, rows contain apartments and cells of the matrix contain values of attributes for a particular apartment.

Table 4 presents the normalised values of attributes, calculated according (2).

Table 5 presents the normalized preferences with assigned weights to attributes (see Step 3 and Step 4).

Table 3. Decision-making matrix of the 6 apartments situated in Naujoji Vilnia, Vilnius

\begin{tabular}{|c|c|c|c|c|c|c|c|}
\hline \multirow{2}{*}{ House No } & \multicolumn{7}{|c|}{ Attributes and their measuring units } \\
\hline & $\begin{array}{l}\text { Air } \\
\text { exchange }\end{array}$ & $\begin{array}{l}\text { Relative } \\
\text { air } \\
\text { humidity }\end{array}$ & $\begin{array}{l}\text { Air } \\
\text { temperature }\end{array}$ & $\begin{array}{l}\text { Air } \\
\text { velocity }\end{array}$ & $\begin{array}{l}\text { Surface } \\
\text { area to } \\
\text { volume } \\
\text { ratio }\end{array}$ & $\begin{array}{l}\text { Noise } \\
\text { isolation }\end{array}$ & $\begin{array}{l}\text { Annual heat } \\
\text { requirement }\end{array}$ \\
\hline Measure & $\mathrm{m}^{3} / \mathrm{h}$ & $\%$ & ${ }^{\circ} \mathrm{C}$ & $\mathrm{m} / \mathrm{s}$ & $1 / \mathrm{m}$ & $\mathrm{dB}$ & $\mathrm{kWh} / \mathrm{m}^{2} /$ year \\
\hline$w_{j}$ & 0,1071 & 0,1429 & 0,2143 & 0,0714 & 0,0357 & 0,1786 & 0,2500 \\
\hline 1 & 17 & 54 & 16 & 0,12 & 0,2019 & 57 & 145 \\
\hline 2 & 12 & 45 & 20 & 0,16 & 0,2019 & 58 & 142 \\
\hline 3 & 18 & 58 & 21 & 0,19 & 0,4044 & 60 & 140 \\
\hline 4 & 19 & 60 & 18 & 0,17 & 0,2891 & 56 & 137 \\
\hline 5 & 23 & 65 & 16 & 0,08 & 0,3321 & 59 & 139 \\
\hline \multirow[t]{2}{*}{6} & 21 & 63 & 19 & 0,10 & 0,3563 & 61 & 146 \\
\hline & $\max$ & $\min / \max$ & $\min / \max$ & $\min / \max$ & $\min$ & $\min$ & $\min$ \\
\hline $\begin{array}{l}\text { Optimal } \\
\text { value }\end{array}$ & $\leq 90$ & 50 & 22 & 0,17 & 0,2019 & 55 & $\leq 15$ \\
\hline
\end{tabular}

Min - minimizing; $\max$ - maximizing; $\min / \max$ - minimizing or maximizing - it depends on the real value of the attribute, if an attribute value is greater/lower than optimal value, it should be minimized/maximized.

Table 4. Normalised decision-making matrix of the 6 apartments in Naujoji Vilnia, Vilnius

\begin{tabular}{|c|c|c|c|c|c|c|c|}
\hline \multirow[t]{2}{*}{ House No } & \multicolumn{7}{|c|}{ Normalised attributes } \\
\hline & $\begin{array}{l}\text { Air } \\
\text { exchange }\end{array}$ & $\begin{array}{l}\text { Relative } \\
\text { air } \\
\text { humidity }\end{array}$ & $\begin{array}{l}\text { Air } \\
\text { temperature }\end{array}$ & $\begin{array}{l}\text { Air } \\
\text { velocity }\end{array}$ & $\begin{array}{l}\text { Surface area } \\
\text { to volume } \\
\text { ratio }\end{array}$ & $\begin{array}{l}\text { Noise } \\
\text { isolation }\end{array}$ & $\begin{array}{l}\text { Annual heat } \\
\text { requirement }\end{array}$ \\
\hline Measure & $\mathrm{m}^{3} / \mathrm{h}$ & $\%$ & ${ }^{\circ} \mathrm{C}$ & $\mathrm{m} / \mathrm{s}$ & $1 / \mathrm{m}$ & $\mathrm{dB}$ & $\mathrm{kWh} / \mathrm{m}^{2} /$ year \\
\hline$w_{j}$ & 0,1071 & 0,1429 & 0,2143 & 0,0714 & 0,0357 & 0,1786 & 0,2500 \\
\hline 1 & 0,3720349 & 0,3592106 & 0,3186012 & 0,3095293 & 0,2592429 & 0,3712272 & 0,4178483 \\
\hline 2 & 0,2626129 & 0,2993422 & 0,3982515 & 0,4127057 & 0,2592429 & 0,3777400 & 0,4092032 \\
\hline 3 & 0,3939193 & 0,3858188 & 0,4181641 & 0,4900880 & 0,5192539 & 0,3907655 & 0,4034398 \\
\hline 4 & 0,4158037 & 0,3991229 & 0,3584264 & 0,4384998 & 0,3712217 & 0,3647144 & 0,3947946 \\
\hline 5 & 0,5033413 & 0,4323831 & 0,3186012 & 0,2063529 & 0,4263262 & 0,3842527 & 0,4005581 \\
\hline \multirow[t]{2}{*}{6} & 0,4595725 & 0,4190790 & 0,3783390 & 0,2579411 & 0,4573785 & 0,3972782 & 0,4207301 \\
\hline & $\max$ & $\min / \max$ & $\min / \max$ & $\min / \max$ & $\min$ & $\min$ & $\min$ \\
\hline $\begin{array}{l}\text { Optimal } \\
\text { value }\end{array}$ & 0,5077182 & 0,3326024 & 0,4380767 & 0,4384998 & 0,2592429 & 0,3582017 & 0,0432257 \\
\hline
\end{tabular}


Table 5. Normalized preferences with assigned weights to attributes to the 6 apartments in Naujoji Vilnia, Vilnius

\begin{tabular}{|c|c|c|c|c|c|c|c|c|}
\hline \multirow[b]{2}{*}{ 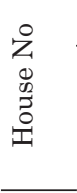 } & \multicolumn{7}{|c|}{ Normalized preferences with assigned weights to attributes } & \multirow[b]{2}{*}{$y_{i}$} \\
\hline & $\begin{array}{l}\text { Air } \\
\text { exchange }\end{array}$ & $\begin{array}{l}\text { Relative } \\
\text { air } \\
\text { humidity }\end{array}$ & $\begin{array}{l}\text { Air } \\
\text { temperature }\end{array}$ & $\begin{array}{l}\text { Air } \\
\text { velocity }\end{array}$ & $\begin{array}{l}\text { Surface area } \\
\text { to volume } \\
\text { ratio }\end{array}$ & $\begin{array}{l}\text { Noise } \\
\text { isolation }\end{array}$ & $\begin{array}{l}\text { Annual } \\
\text { heat } \\
\text { require- } \\
\text { ment }\end{array}$ & \\
\hline 1 & 0,039844937 & 0,051331195 & 0,068276243 & 0,022100392 & 0,009254971 & 0,066301179 & 0,10446209 & $-0,1011279$ \\
\hline 2 & 0,028125838 & 0,042775996 & 0,085345303 & 0,029467189 & 0,009254971 & 0,067464357 & 0,1023008 & 0,0066942 \\
\hline 3 & 0,042188757 & 0,055133506 & 0,089612568 & 0,034992287 & 0,018537365 & 0,069790714 & 0,10085995 & $-0,1475125$ \\
\hline 4 & 0,044532577 & 0,057034661 & 0,076810773 & 0,031308888 & 0,013252615 & 0,065138 & 0,09869866 & $-0,0814717$ \\
\hline 5 & 0,053907856 & 0,06178755 & 0,068276243 & 0,014733594 & 0,015219846 & 0,068627536 & 0,10013952 & $-0,1088568$ \\
\hline 6 & 0,049220216 & 0,059886395 & 0,081078038 & 0,018416993 & 0,016328414 & 0,070953893 & 0,10518252 & $-0,1036360$ \\
\hline 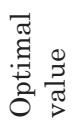 & 0,05437662 & 0,047528885 & 0,093879834 & 0,031308888 & 0,009254971 & 0,063974821 & 0,01080642 & 0,1430580 \\
\hline
\end{tabular}

Now, it is possible to determine the best alternative among six compared apartments and the deviation of each alternative (an indoor environment of an apartment) from the optimal value. For this purpose the preference $y_{O}$ of the optimal value (the ideal solution), which equals to 0,1430580 , is compared with the preferences $y_{i}$ of each alternative (see Table 4). The comparison is presented in Figure 2.

As can be seen from the comparison (Figure 2), the second apartment has the best in- door environment compared to others. However, the indoor environment of all six apartments does not meet the ideal environment. This is because of high annual heat requirements of each apartment. Other attributes, like relative air humidity and noise isolation should be minimized. Surface area to volume ratio can not be changed, though, it is not optimal. Therefore, they $y_{i}$ value of almost all alternatives is negative.

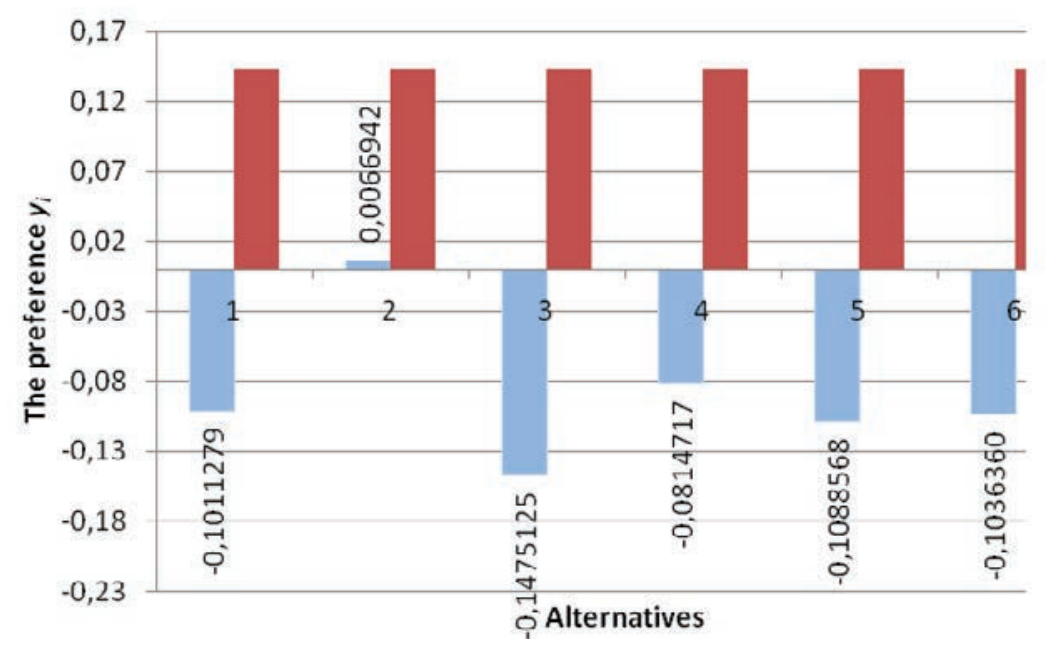

Figure 2. The comparison of the preferences $y_{i}$ of the 6 apartments in Naujoji Vilnia, Vilnius, Lithuania (dark columns) with the ideal indoor environment (light columns) 


\section{CONCLUSIONS}

The analysis of the related work on MADM methods shows that because of a number of MADM methods and techniques a problem of choosing a suitable one arises. The analysis of six MADM methods (the Weighted Sum Model (WSM), the Weighted Product Model (WPM), the Analytic Hierarchy Process (AHP), ELECTRE, COPRAS and TOPSIS) shows that none of the methods reviewed below uses the concept of the global ideal solution or global ideal alternative, which means the best possible alternative in a space and based on standards, norms and regulations. The comparison of chosen alternatives with the global ideal alternative is important, since it allows determining the deviation from and matching the chosen alternatives with the ideal ones. All alternatives chosen for the assessment can be far from the optimal one and the comparison among them does not present the global view.

The proposed method of multi-attribute assessment using ideal alternative (MAAIA) allows evaluating both the selected alternatives (in this paper - the current state of an indoor environment of dwelling-houses) and the deviation of each alternative (an indoor environment of dwelling-houses) from the optimal value (ideal alternative).

In this paper, the MOORA method is applied for MAAIA to assess six apartments and the obtained results are presented. According to the related work on indoor air, seven attributes were selected: air exchange $\left(\mathrm{m}^{3} / \mathrm{h}\right)$, relative air humidity (percents), air temperature (C), air velocity (m/s), surface area to volume ratio $(1 / \mathrm{m})$, noise isolation $(\mathrm{dB})$ and annual heat requirement $\left(\mathrm{kWh} / \mathrm{m}^{2} /\right.$ year $)$.

The experimental data, obtained by assessing six apartments in apartment houses situated in Naujoji Vilnia, Vilnius, Lithuania, shows that the second apartment has the best indoor environment. However, the indoor environment of all six apartments does not meet the ideal environment, determined according to the Lithuanian hygienic norm, ISO EN 7730 and the Passive House standard. A high annual heat requirement and air temperature have a strong impact on indoor environment. A high annual heat requirement is not acceptable in all six apartments. Other values of attributes, like air temperature for the first and fifth alternatives, are below acceptable values.

The results presented in this paper show that the proposed method can be used to evaluate an indoor environment and to determine does it meet standards.

The next step of the research could be aimed at extending and verifying the proposed method and defining the particular attributes to determine the validity of the method.

\section{REFERENCES}

Antucheviciene, J., Zavadskas, E. K. and Zakarevicius, A. (2010) Multiple criteria construction management decisions considering relations between criteria, Technological and Economic Development of Economy, 16(1), pp. 109-125. http://dx.doi.org/10.3846/tede.2010.07

Antucheviciene, J., Zakarevicius, A., and Zavadskas, E. K. (2011) Measuring congruence of ranking results applying particular MCDM methods, Informatica, 22(3), pp. 319-338.

Balezentis, T., Balezentis, A., and Brauers, W. K. M. (2011) Multi-objective optimization of wellbeing in the European union member states, Ekonomska istraživanja-Economic Research, 24 (4), pp.1-15.

Baležentis, A., Baležentis, T. (2011) An Innovative Multi-criteria Supplier Selection Based on Two-tuple MULTIMOORA and Hybrid Data, Economic Computation and Economic Cybernetics Studies and Research 45(2), pp. 37-56.

Banaitienè, N., Banaitis, A. and Norkus, A. (2011) Risk management in projects: peculiarities of Lithuanian construction companies, International Journal of Strategic Property Management, 15(1), pp. 60-73. http://dx.doi.org/10.384 6/1648715X.2011.568675

Belton, V. and Gear, T. (1983) On a short-coming of Saaty's method of analytic hierarchies, 
Omega, 11(3), pp. 228-230. http://dx.doi. org/10.1016/0305-0483(83)90047-6

Bluyssen, P. M. (2008) Management of the indoor environment: from a component related to an interactive top-down approach, Indoor and Built Environment, 17(6), pp. 483-495. http://dx.doi.org/10.1177/1420326X08098687

Boyce, P. R. (2010) Review: The impact of light in buildings on human health, Indoor and Built Environment, 19(1), pp. 8-20. http://dx.doi.org/10.1177/1420326X09358028

Braubach, M. (2007) Residential conditions and their impact on residential environment satisfaction and health: results of the WHO large analysis and review of European housing and health status (LARES) study, International Journal of Environment and Pollution, 30(3/4), pp. 384-403.

http://dx.doi.org/10.1504/IJEP.2007.014817

Brauers, W. K. M., and Zavadskas, E. K. (2006) The MOORA method and its application to privatization in a transition economy, Control and Cybernetics, 35(2), pp. 183-19

Brauers, W. K. M., Zavadskas, E. K., Peldschus, F. and Turskis, Z. (2008b) Multiobjective decision-making for road design, Transport, 23(3), pp. 183-193. http://dx.doi.org/10.3846/16484142.2008.23.183-193

Brauers, W. K. M. and Zavadskas, E. K. (2009) Robustness of the multi-objective MOORA method with a test for the facilities sector, Technological and Economic Development of Economy, 15(2), pp. 352-375. http://dx.doi. org/10.3846/1392-8619.2009.15.352-375

Brauers, W. K. M., Balezentis, A. and Balezentis, T. (2011) Multimoora for the EU member states updated with fuzzy number theory, Technological and Economic Development of Economy, 17(2), pp. 259-290. http://dx.doi.org/10.3846/2 0294913.2011 .580566

Brauers, W. K. M., Ginevicius, R. and Podvezko, V. (2010) Regional development in Lithuania considering multiple objectives by the MOORA method, Technological and Economic Development of Economy, 16(4), pp. 613-640. http://dx.doi.org/10.3846/tede.2010.38

Bridgman, P. W. (1922) Dimensional analysis. New Haven, CT, U.S.A.: Yale University Press.

Chakraborty, Sh. (2011) Applications of the MOORA method for decision making in manufacturing environment, The International Journal of
Advanced Manufacturing Technology, 54(9-12), pp. $1155-1166$, http://dx.doi.org/10.1007/s00170-010-2972-0

Cheong, K. W. D., Yu, W. J., Kosonen, R., Tham, K. W. and Sekhar, S. C. (2006) Assessment of thermal environment using a thermal manikin in a field environment chamber served by displacement ventilation system, Building and Environment, 41(12), pp. 1661-1670. http://dx.doi. org/10.1016/j.buildenv.2005.06.018

Greening, L. A. and Bernow, S. (2004) Design of coordinated energy and environmental policies: use of multi-criteria decision-making, Energy Policy, 32(6), pp. 721-735.

http://dx.doi.org/10.1016/j.enpol.2003.08.017

Gulyas, A., Unger, J. and Matzarakis, A. (2006) Assessment of the microclimatic and human comfort conditions in a complex urban environment: Modelling and measurements, Building and Environment, 41(12), pp. 1713-1722. http://dx.doi.org/10.1016/j.buildenv.2005.07.001

HN 42:2009: Microclimate of residential and administrative buildings. Lithuanian Hygienic Norm. Zin., 2009, Nr. 159-7219. (in Lithuanian)

Hui, P. S., Wong, L. T. and Mui, K. W. (2007) Evaluation of professional choice of sampling locations for indoor air quality assessment, Building and Environment, 42(8), pp. 2900-2907. http://dx.doi.org/10.1016/j.buildenv.2006.10.039

Hui, P. S., Wong, L. T. and Mui, K. W. (2008) Using carbon dioxide concentration to assess indoor air quality in offices, Indoor and Built Environment, 17(3), pp. 213-219. http://dx.doi.org/10.1177/1420326X08091773

Hwang, C. L. and Yoon, K. (1981) Multiple attribute decision making - methods and applications, a state-of-the-art survey, Springer Verlag, Berlin.

ISO EN 7730 2005: Moderate thermal environments Determination of the PMV and PPD indices and specification of the conditions for thermal comfort. International Standards Organisation. Geneva.

Kaklauskas, A., Rutè, J., Gudauskas, R. and Banaitis, A. (2011) Integrated model and system for passive houses multiple criteria analysis, International Journal of Strategic Property Management, 15(1), 74-90. http://dx.doi.org/10.3846/1648715X.2011.574903

Kaklauskas, A., Zavadskas, E. K. and Raslanas, S. (2005) Multivariant design and multiple crite- 
ria analysis of building refurbishments, Energy and Buildings, 37(4), pp. 361-372.

http://dx.doi.org/10.1016/j.enbuild.2004.07.005

Kaklauskas, A., Zavadskas, E. K., Naimaviciene, J., Krutinis, M., Plakys, V. and Venskus, D. (2010) Model for a complex analysis of intelligent built environment, Automation in Construction, 19(3), pp. 326-340.

http://dx.doi.org/10.1016/j.autcon.2009.12.006

Kalibatas, D., Zavadskas, E. K. and Kalibatiene, D. (2011) The concept of the ideal indoor environment in multi-attribute assessment of dwelling-houses, Archives of Civil and Mechanical Engineering, 11(1), pp. 89-101. http://dx.doi. org/10.1016/S1644-9665(12)60176-9

Kavraz, M. and Abdulrahimov, R. (2009) A study comparing the noise reduction behavior of variously shaped barriers of limited size in indoor spaces, Indoor and Built Environment, 18(6), pp. 541-552.

http://dx.doi.org/10.1177/1420326X09346225

Kendall, M. G. (1970) Rank correlation methods, 4th ed. Griffin, London.

Latif, M. T., Othman, M. R., Kim, C. L., Murayadi, S. A. and Sahaimi K. N. A. (2009) Composition of household dust in semi-urban areas in Malaysia, Indoor and Built Environment, 18(2), pp. 155-161.

http://dx.doi.org/10.1177/1420326X09103014

Ludeman, C. (2008) Passive house (Passivhaus) standard for energy efficient design. [Online]. Available at: http://www.100khouse. com/2008/04/10/passive-house-passivhausstandard-for-energy-efficient-design/ [accessed 15 January 2009]

Martinaitis, V., Kazakevicius, E. and Vitkauskas, A. (2007) A two-factor method for appraising building renovation and energy efficiency improvement projects, Energy Policy, 35(1), pp. 192-201.

http://dx.doi.org/10.1016/j.enpol.2005.11.003

Martinaitis, V., Rogoza, A. and Bikmaniene, I. (2004) Criterion to evaluate the "twofold benefit" of the renovation of buildings and their elements, Energy and Buildings, 36(1), pp. 3-8. http:// dx.doi.org/10.1016/S0378-7788(03)00054-9

Medineckiene, M., Zavadskas, E. K. and Turskis, Z. (2011) Dwelling selection by applying fuzzy game theory, Archives of Civil and Mechanical Engineering, 11(3), pp. 681-697.

http://dx.doi.org/10.1016/S1644-9665(12)60109-5
Miller, D. W. and Starr, M. K. (1969) Executive decisions and operations research. Englewood Cliffs, NJ, U.S.A.: Prentice-Hall, Inc.

Mui, K. W. and Chan, W. T. (2006) Building calibration for IAQ management, Building and Environment, 41(7), pp. 877-886.

http://dx.doi.org/10.1016/j.buildenv.2005.04.019

NuTech Renewables (2011) Five performance criteria for passive house standard. [Online] Available at: http://nutechrenewables.com/architect/ five-design-criteria-for-designing-passive-houses.html [accessed 10 September 2011]

Olesen, B. W. (2004) International standards for the indoor environment, Indoor Air, 14(7), pp. 18-26. http://dx.doi.org/10.1111/j.1600-0668.2004.00268.x

Opricovic, S. and Tzeng, G. H. (2004) Compromise solution by MCDM methods: A comparative analysis of VIKOR and TOPSIS, European Journal of Operational Research, 156(2), pp. 445-455. http://dx.doi.org/10.1016/S03772217(03)00020-1

PHI (2010) What is a passive house? [Online] Passive House Institute. Available at: http://www. passivehouse.us/passiveHouse/PassiveHouseInfo.html [accessed 10 September 2011]

Podvezko, V., Mitkus, S. and Trinkuniene, E. (2010) Complex evaluation of contracts for construction, Journal of Civil Engineering and Management, 16(2), pp. 287-297.

http://dx.doi.org/10.3846/jcem.2010.33

Radziszewska-Zielina, E. (2010) Methods for selecting the best partner construction enterprise in terms of partnering relations, Journal of Civil Engineering and Management, 16(4), pp. 510520. http://dx.doi.org/10.3846/jcem.2010.57

Rutman, E., Inard, C., Bailly, A. and Allard, F. (2005) A global approach of indoor environment in an air-conditioned office room, Building and Environment, 40(1), pp. 29-37. http:// dx.doi.org/10.1016/j.buildenv.2004.05.006

Saaty, T. L. and Vargas, L. G. (2001) Models, methods, concepts \& applications of the analytic hierarchy process. Kluwer's International Series.

Seppanen, O. and Vuolle, M. (2000) Cost effectiveness of some remedial measures to control summer time temperatures in an office building. In: Proc. of sixth international conference "Healthy buildings 2000”, Finland. 1, pp. 665-670. 
Singh, J., Yu, C. W. F. and Kim, J. T. (2010) Building pathology, investigation of sick buildings toxic moulds, Indoor and Built Environment, 19(1), pp. 40-47. http://dx.doi.org/10.1177/1420326X09358808

SPHC (2012) Ventilation in an airtight building. [Online] The Scottish Passivhaus Centre (SPHC). Available at: http://www.sphc.co.uk/ ventilation-airtight-building [accessed 16 April 2012]

STR 2.01.07:2003. Noise protection of inside and outside environment. Zin., 2003, Nr. 79-3614.

STR 2.09.02:2005. Heating, ventilation and air exchange. Zin., 2005, Nr. 75-2729.

Triantaphyllou, E. (2000) Multi-criteria decision making methods: A comparative study, Springer.

Venckus, N., Bliudzius, R., Endriukaityte, A. and Parasonis, J. (2010) Research of low energy house design and construction opportunities in Lithuania, Technological and Economic Development of Economy, 16(3), pp. 541-554. http://dx.doi.org/10.3846/tede.2010.33

Vilcekova, S. and Senitkova, I. (2009) Modeling the occurrence of nitrogen oxides indoors, Indoor and Built Environment, 18(2), pp. 138-143. http://dx.doi.org/10.1177/1420326X09103331

Wong, L. T., Mui, K. W. and Hui, P. S. (2006) A statistical model for characterizing common air pollutants in air-conditioned offices, Atmospheric Environment, 40(23), pp. 4246-4257. http:// dx.doi.org/10.1016/j.atmosenv.2006.04.005

Yazdani, M., Alidoosti, A. and Zavadskas, E. K. (2011) Risk analysis of critical infrastructures using fuzzy COPRAS, Ekonomska IstrazivanjaEconomic Research, 24(4), pp. 27-40.

Yik, F. W. H. and Lun, Y. F. (2010) Energy saving by utilizing natural ventilation in public housing in Hong Kong, Indoor and Built Environment, 19(1), pp. 73-87. http://dx.doi.org/10.1177/1420326X09358021

Zanakis, S. H., Solomon, A., Wishart, N. and Dublish, S. (1998) Multi-attribute decision making: A simulation comparison of select methods, European Journal of Operational Research, 107(3), pp. 507-529. http://dx.doi.org/10.1016/ S0377-2217(97)00147-1
Zavadskas, E. K. and Turskis, Z. (2011) Multiple criteria decision making (MCDM) methods in economics: an overview, Technological and Economic Development of Economy, 17(2), pp. 397-427. http://dx.doi.org/10.3846/20294913.2011.593291

Zavadskas, E. K., Turskis, Z. and Tamosaitiene, J. (2011) Selection of construction enterprises management strategy based on the SWOT and multi-criteria analysis, Archives of Civil and Mechanical Engineering, 11(4), pp. 1063-1082. http://dx.doi.org/10.1016/S1644-9665(12)60096-X

Zavadskas, E. K., Raslanas, S. and Kaklauskas, A. (2008) The selection of effective retrofit scenarios for panel houses in urban neighborhoods based on expected energy savings and increase in market value: The Vilnius case, Energy and Buildings, 40(4), pp. 573-587. http://dx.doi. org/10.1016/j.enbuild.2007.04.015

Zavadskas, E. K., Turskis, Z. and Tamosaitiene, J. (2010a) Risk assessment of construction projects, Journal of Civil Engineering and Management, 16(1), pp. 33-46. http://dx.doi.org/10.3846/jcem.2010.03

Zavadskas, E. K., Turskis, Z. and Vilutiene, T. (2010b) Multiple criteria analysis of foundation instalment alternatives by applying Additive Ratio Assessment (ARAS) method, Archives of Civil and Mechanical Engineering, 10(3), pp. 123-141. http://dx.doi.org/10.1016/S1644-9665(12)60141-1

Zavadskas, E. K., Turskis, Z., Ustinovichius, L. and Shevchenko, G. (2010c) Attributes weights determining peculiarities in multiple attribute decision making methods, Inzinerine Ekonomika-Engineering Economics, 21(1), pp. 32-43.

Zavadskas, E. K. (1987) Kompleksnaia otsenka $i$ vybor resursosberegaiushchikh rechenij $v$ stroitelstve. Vilnius: Mokslas (in Russian).

Zavadskas, E. K., Kaklauskas, A., Turskis, Z., Tamosaitiene, J. and Kalibatas, D. (2011) Assessment of the indoor environment of dwelling houses by applying the COPRAS-G method: Lithuania case study, Environmental Engineering and Management Journal, 10(5), pp. 637-647. 